\title{
Effective Medicinal Plants in the Treatment of the Cyclic Mastalgia (Breast Pain): A Review
}

\author{
Azin Niazi ${ }^{1+}$, Vafa Baradaran Rahimi ${ }^{1,2+}$, Hooman Hatami ${ }^{1+}$, Reza Shirazinia ${ }^{6}$, \\ Reza Esmailzadeh-dizaji ${ }^{3}$, Nafiseh Askari ${ }^{4}$, Vahid Reza Askari 1, 2,5*
}

${ }^{1}$ Pharmacological Research Center of Medicinal Plants, Mashhad University of Medical Sciences, Mashhad, Iran

${ }^{2}$ Student Research Committee, Department of Pharmacology, Faculty of Medicine, Mashhad University of Medical Sciences, Mashhad, Iran

${ }^{3}$ Avian Diseases, Faculty of Veterinary Medicine, University of Tehran, Iran

${ }^{4}$ Student Research Committee, Sabzevar University of Medical Sciences, Sabzevar, Iran

${ }^{5}$ Neurogenic Inflammation Research Center, Mashhad University of Medical Sciences, Mashhad, Iran

${ }^{6}$ Basic Science Department, Veterinary Medicine Faculty, University of Zabol, Zabol, Iran

\section{Key Words}

mastalgia, herbal medicine, breast pain.

\begin{abstract}
Introduction: Mastalgia is the most common benign breast disorder during the fertility period of women. So far a wide range of natural or complementary medicines is used to cure mastalgia. Sanitary organizations need complete and suitable details to help women, for making the proper decision for alternative treatment based on the evidence. The aim of the present study is to introduce medicinal plant-based treatments about mastalgia and summarizes clinical trials about this disorder.
\end{abstract}

Method: The articles were provided using mixture of keywords including cyclic pain, breast, treatment, therapeutics, therapy, clinical trial, herbal, drug, mastalgia and all the probable terms, in national and international databases SID, Iran Medex, Magiran, PubMed, Scopus, Medline, Science direct and Cochrane library, in both Persian and English languages. All cross-sectional and review articles about herbal treatment of mastalgia until 2018 November were studied.

Received: Feb 02, 2019 Reviewed: Apr 15, 2019 Accepted: May 31, 2019

(c) This is an Open-Access article distributed under the terms of the Creative Common Attribution Non-Commercial License (http://creativecommons.org/licenses/by-nc/4.0/) which permits unrestricted noncommercial use, distribution, and reproduction in any medium, provided the original work is properly cited.

@ This paper meets the requirements of KS X ISO 9706, ISO 9706-1994 and ANSI/NISO Z39.48-1992 (Permanence of Paper).
Results: Nineteen articles from all of the available articles ( 45 cases) and a sample size about of (1987 cases) were included in our study. The articles were clinical trials. The results revealed that mastalgia could be healed by Nigella sativa, Vitex agnus-castus, curcumin, Hypericum perforatum, Citrus sinensis, wheat germ, and Ginkgo biloba.

Conclusion: Most of the evaluated medicinal plants possessing antioxidant compounds with anti-inflammatory and analgesic properties, exhibited healing effects in the treatment of mastalgia. Thus, medicinal plants can be considered in the treatment of mastalgia; however, further investigations are needed to obtain more details about their probable side effects.

\section{Introduction}

Asthma is a Mastalgia is considered the most common benign breast disorder in women during the fertile period by a prevalence rate of about $65 \%$ [1-3]. By definition, mastalgia is the breast tenderness before the menstruation cycle in the luteal phase [4]. Given the nature and its response to the treatment, Mastalgia is divided into 4 groups including cyclic mastalgia, acyclic mastalgia, chest pain, and unrelated chest pain [5]. By prevalence, the cyclic mastalgia is the most common type of mastalgia by about two third of referring the mastalgia cases to the physicians [6]. Cyclic mastalgia may be caused by endocrine changes including 
an increment in the levels of estrogen, prolactin, estrogen/ progesterone ratio, and their receptors susceptibility due to the decrement of unsaturated/saturated fatty acids ratio, and decreases in the levels of progesterone, FSH, LH, and androgens, the main reason is still unknown [7].

Non-medical treatment of cyclic mastalgia consists of an increment of mothers' awareness and self-confidence about breastfeeding is still known as the easiest way for surmounting the antidiuretics, hormone-modifying drugs, and hormone replacement therapy, vitamins (E, B6) and nutritional supplements, mechanical preservations, and reducing the fat and caffeine derivatives consumption [7-11].

Nowadays, many studies advise the use of medicinal plants due to their curative role in many disorders [12]. In fact, Medicinal plants may be compatible with our body condition and possess more efficacy and likely lesser side effects [13]. According to the world health organization (WHO) reports, about $80 \%$ of people all around the world are using medicinal plants for many medical purposes [14]. In this regard, unknown exact pathophysiology, and involvement of various psychological, metabolic and nutritional causes in cyclic mastalgia made a difficulty and complication in its treatment [15]. Therefore, in the present study, we aimed to review the medicinal plants that use in the treatment of mastalgia and summarize their clinical trials.

\section{Material and method}

The articles were included in this research were cross-sectional and review articles about herbal treatments of mastalgia in various electronic databases as SID, Iran Medex, Magiran, PubMed, Scopus, Medline, Science Direct, and Cochrane library. These studies are in both Persian and English languages that published until 2018 November. Keywords are mastalgia, cyclic pain, pain, breast, treatment, therapeutic, therapy, clinical trial, herbal, drug, medication and their combination, and their Persian language equivalent terms. To make a comprehensive search, a table containing about all of the related topics was provided manually to access all of the probable search items. The exclusion criteria for articles in our research were inaccessibility to the full text, lack of essential data for our research, animal studies, and simultaneous intervention of several drugs/placebo in one group, experimental and non-experimental studies, and before and after clinical trials. Quality evaluation of the articles used in the present study was based on the consort role in manuscript publication.

Table 1 Trials in the treatment of cyclic mastalgia

\begin{tabular}{|c|c|c|c|c|c|c|c|}
\hline References & Location & Author/year & Method & $\begin{array}{l}\text { Research } \\
\text { society }\end{array}$ & Intervention group/group1 & Control group/group2 & Tools \\
\hline 22 & Tehran & $\begin{array}{l}\text { Mirmolaei } \\
\text { (2017) }\end{array}$ & $\begin{array}{l}\text { Triple- } \\
\text { blind } \\
\text { clinical } \\
\text { trial }\end{array}$ & $\begin{array}{l}72 \text { women } \\
\text { with cyclic } \\
\text { mastalgia }\end{array}$ & $\begin{array}{l}\text { Nigella Sativa syrup, } 10 \mathrm{ml} / \text { day, } \\
\text { equivalent to two spoons. evaluation two } \\
\text { months before intervention until three } \\
\text { months after treatment }\end{array}$ & $\begin{array}{l}\text { Oral paraffin syrup, } 10 \mathrm{ml} / \mathrm{day} \text {, } \\
\text { equivalent to two spoons. } \\
\text { Evaluation two months before the } \\
\text { intervention up to three months after } \\
\text { treatment }\end{array}$ & $\begin{array}{l}\text { Mc Gill, } \\
\text { VAS }\end{array}$ \\
\hline 26 & Tehran & $\begin{array}{l}\text { Mirmolaei } \\
\text { (2016) }\end{array}$ & $\begin{array}{l}\text { Triple- } \\
\text { blind } \\
\text { clinical } \\
\text { trial }\end{array}$ & $\begin{array}{l}\text { 72women with } \\
\text { cyclic } \\
\text { mastalgia }\end{array}$ & $\begin{array}{l}\text { First group: Vitex agnus-castus syrup34 } \\
\text { people, } \\
\text { Evaluation two months before the } \\
\text { intervention up to three months after } \\
\text { treatment }\end{array}$ & $\begin{array}{l}\text { second group: Oral paraffin syrup } 33 \\
\text { people, Evaluation two months before } \\
\text { the intervention up to three months after } \\
\text { treatment }\end{array}$ & $\begin{array}{l}\text { Mc Gill, } \\
\text { VAS }\end{array}$ \\
\hline 27 & Yazd & $\begin{array}{l}\text { Sekhavat } \\
(2009)\end{array}$ & $\begin{array}{l}\text { Double- } \\
\text { blind } \\
\text { clinical } \\
\text { trial }\end{array}$ & $\begin{array}{l}117 \text { women } \\
\text { with cyclic } \\
\text { mastalgia }\end{array}$ & $\begin{array}{c}\text { Vitex agnus-castus } 60 \text { drops daily } 55 \\
\text { people }\end{array}$ & $\begin{array}{c}\text { Placebo } \\
62 \text { people } \\
\text { Evaluation three months later }\end{array}$ & NAM \\
\hline 28 & Paraguay & $\begin{array}{l}\text { Halaska } \\
\text { (1999) }\end{array}$ & $\begin{array}{l}\text { Double- } \\
\text { blind } \\
\text { clinical } \\
\text { trial }\end{array}$ & $\begin{array}{l}\text { 97women with } \\
\text { cyclic } \\
\text { mastalgia }\end{array}$ & $\begin{array}{l}\text { Vitex agnus-castus } 60 \text { drops daily } \\
48 \text { people }\end{array}$ & $\begin{array}{c}\text { Placebo } \\
49 \text { people } \\
\text { Evaluation } 1,2 \text { and } 3 \text { months later }\end{array}$ & VAS, \\
\hline 11 & $\begin{array}{l}\text { Qaem } \\
\text { Shahr }\end{array}$ & $\begin{array}{l}\text { Alvandi } \\
(2010)\end{array}$ & $\begin{array}{l}\text { Double- } \\
\text { blind } \\
\text { clinical } \\
\text { trial }\end{array}$ & $\begin{array}{l}100 \text { women } \\
\text { with cyclic } \\
\text { mastalgia }\end{array}$ & $\begin{array}{c}\text { Oenothera biennis extract ( } 2 \mathrm{~g} \text { per day) } \\
\text { Vitamin E ( } 400 \mathrm{IU} \text { daily), Oenothera } \\
\text { biennis extract + Vitamin E. } 25 \text { people in } \\
\text { each group }\end{array}$ & $\begin{array}{c}\text { Placebo } \\
49 \text { people } \\
\text { Evaluation after } 1 \text {, and } 6 \text { months }\end{array}$ & Mc Gill \\
\hline
\end{tabular}




\begin{tabular}{|c|c|c|c|c|c|c|c|}
\hline 60 & Arak & Salehi (2013) & $\begin{array}{l}\text { Triple- } \\
\text { blind } \\
\text { clinical } \\
\text { trial }\end{array}$ & $\begin{array}{l}210 \text { women } \\
\text { with cyclic } \\
\text { mastalgia }\end{array}$ & $\begin{array}{c}\text { First group Vitex agnus-castus tablet } 4 \mathrm{mg} \\
\text { daily Second group three Oenothera } \\
\text { biennis capsule } 500 \mathrm{mg} \text { daily }\end{array}$ & $\begin{array}{l}\text { Control group: a } 400 \text {-unit Vitamin } \mathrm{E} \\
\text { capsule daily for two months }\end{array}$ & $\begin{array}{l}\text { NAM, } \\
\text { Cardiff } \\
\text { chart }\end{array}$ \\
\hline 37 & Mashhad & $\begin{array}{l}\text { Jaafarnejad } \\
\text { (2016) }\end{array}$ & $\begin{array}{l}\text { Clinical } \\
\text { trial }\end{array}$ & $\begin{array}{l}\text { 90women with } \\
\text { cyclic } \\
\text { mastalgia }\end{array}$ & $\begin{array}{l}\text { First group: Linum usitatissimum capsule } \\
\text { (30g daily), Second group: Two } \\
\text { Oenothera biennis capsules } 1000 \mathrm{mg} \text { daily } \\
\text { Third group: a } 400 \text { units Vitamin E } \\
\text { capsule daily } \\
\text { Evaluation after } 2 \text { months }\end{array}$ & - & VAS \\
\hline 1 & Shiraz & $\begin{array}{l}\text { Vaziri } \\
(2014)\end{array}$ & $\begin{array}{l}\text { Clinical } \\
\text { trial }\end{array}$ & $\begin{array}{l}180 \text { women } \\
\text { with cyclic } \\
\text { mastalgia }\end{array}$ & $\begin{array}{l}\text { First group: Linum usitatissimum diet } \\
\text { bread } 30 \mathrm{~g} \text { daily, Second group: Omega3 } \\
\qquad 1 \mathrm{~g} \text { daily }\end{array}$ & $\begin{array}{l}\text { Control group: wheat bread } \\
\text { Evaluation for } 2 \text { months }\end{array}$ & VAS \\
\hline 39 & $\begin{array}{l}\text { Shahr e } \\
\text { Kord }\end{array}$ & $\begin{array}{l}\text { Delaram } \\
(2011)\end{array}$ & $\begin{array}{l}\text { Clinical } \\
\text { trial }\end{array}$ & 60 people & $\begin{array}{c}\text { 30drops Foeniculum vulgare extract/ } 8 \\
\text { hours }\end{array}$ & $\begin{array}{l}\text { Control group: Placebo } \\
\text { Evaluation for } 2 \text { months }\end{array}$ & DSRP \\
\hline 41 & $\begin{array}{l}\text { Shahr e } \\
\text { Kord }\end{array}$ & $\begin{array}{l}\text { Delaram } \\
(2011)\end{array}$ & $\begin{array}{l}\text { Clinical } \\
\text { trial }\end{array}$ & 90 people & $\begin{array}{l}\text { First group: } 30 \text { drops Foeniculum vulgare } \\
\text { extract/8 hours, Second group: } 30 \text { drops } \\
\text { Echinophora platyloba } \text { extract/8 hours }\end{array}$ & $\begin{array}{l}\text { Control group: Placebo } \\
\text { Evaluation after } 2 \text { months }\end{array}$ & DSRP \\
\hline 48 & Tehran & $\begin{array}{l}\text { Khayat } \\
(2015)\end{array}$ & $\begin{array}{l}\text { Clinical } \\
\text { trial }\end{array}$ & 70 people & $\begin{array}{l}\text { Curcumin powder Capsule } 7 \text { days before } \\
\text { till } 3 \text { days after Menstruation two times a } \\
\text { day for } 3 \text { consecutive cycles }\end{array}$ & Control group: $50 \mathrm{mg}$ starch capsule & DSRP \\
\hline 45 & Kazerun & $\begin{array}{l}\text { Sharifi } \\
(2014)\end{array}$ & $\begin{array}{l}\text { Clinical } \\
\text { trial }\end{array}$ & 90 people & $\begin{array}{l}5 \% \text { Curcumin Capsule from } 21^{\text {th }} \text { day of } \\
\text { Menstruation cycle till the start of next } \\
\text { period, three times a day for two } \\
\text { consecutive cycles }\end{array}$ & $\begin{array}{c}\text { Control group: Mefenamic acid capsule } \\
\text { from }{ }^{\text {th }} \text { e } 21 \text { st day of Menstruation cycle } \\
\text { till the start of next period, three times a } \\
\text { day for two consecutive cycles }\end{array}$ & DSRP \\
\hline 44 & Tehran & $\begin{array}{l}\text { Khayat } \\
(2016)\end{array}$ & $\begin{array}{l}\text { Clinical } \\
\text { trial }\end{array}$ & 105 people & $\begin{array}{l}\text { First group: two Zintoma capsules daily, } \\
\text { Second group: two 100mg Curcumin } \\
\text { capsules daily }\end{array}$ & $\begin{array}{l}\text { Control group: Placebo capsule contains } \\
\qquad 50 \mathrm{mg} \text { starch } \\
\text { For three consecutive cycles }\end{array}$ & DSRP \\
\hline 50 & Tehran & $\begin{array}{l}\text { Pakgohar } \\
\text { (2005) }\end{array}$ & $\begin{array}{l}\text { Clinical } \\
\text { trial }\end{array}$ & 70 people & $\begin{array}{l}30 \text { drops Hypiran two times a day } \\
\text { For two consecutive cycles }\end{array}$ & Control group: Placebo drop & DSRP \\
\hline 52 & Arak & $\begin{array}{l}\text { Jamilian } \\
(2017)\end{array}$ & $\begin{array}{l}\text { Clinical } \\
\text { trial }\end{array}$ & 120 people & $\begin{array}{c}\text { First group: A Omeg3 500mg capsule per } \\
\text { day Second group: } 30 \text { drops Rosa } \\
\text { Damascena } \text { oral drop }\end{array}$ & $\begin{array}{l}\text { Control group: Placebo drop } \\
\text { from } 14 \text { days before Menstruation cycle } \\
\text { to end of the cycle } \\
\text { For three consecutive cycles }\end{array}$ & DSRP \\
\hline 55 & Jahrom & $\begin{array}{l}\text { Ataollahi } \\
\text { (2015) }\end{array}$ & $\begin{array}{l}\text { Clinical } \\
\text { trial }\end{array}$ & 100 people & $\begin{array}{l}\text { Wheat Germ } 400 \mathrm{mg} \text { capsule from } 16^{\text {th }} \\
\text { Menstruation cycle to the } 5^{\text {th }} \text { day of next } \\
\text { cycle for two consecutive Months }\end{array}$ & Placebo & DSRP \\
\hline 56 & Tehran & Ozgoli (2010) & $\begin{array}{l}\text { Clinical } \\
\text { trial }\end{array}$ & 80 people & $\begin{array}{l}10 \text { drops of Citrus sinensis essential oil } \\
\text { three times a day at least from } 14^{\text {th }} \text { days } \\
\text { before Menstruation } \\
\text { For two cycles }\end{array}$ & Placebo & DSRP \\
\hline 58 & Paris & $\begin{array}{c}\text { Tamborini } \\
\text { (1993) }\end{array}$ & $\begin{array}{l}\text { clinical } \\
\text { trial }\end{array}$ & 165 people & $\begin{array}{l}\text { standardized Ginkgo biloba extract (EGb } \\
761 \text { ) from the } 16^{\text {th }} \text { day of Menstruation to } \\
\text { the } 5^{\text {th }} \text { day of next cycle for two cycles per } \\
\text { day }\end{array}$ & Placebo & DSRP \\
\hline
\end{tabular}

\section{Result}

Nineteen articles from all of the available articles ( 45 cases) and a sample size about of (1987 cases) were involved in our study. Articles were clinical trials that conducted on Nigella sativa (2 cases), Vitex agnus-castus (5 cases), Oenothera biennis ( 3 cases), Linum usitatissimum ( 2 cases), Foeniculum vulgare (2 cases), Echinosophora platyloba
( 1 case), Curcumin (3 cases), Zingiber officinale (1 cases), Hypericum perforatum (1 case), wheat germ (1 case), Rosa damascena (1 case), Citrus sinensis ( 1 case), Ginkgo biloba ( 1 case).

\subsection{Nigella Sativa}

Nigella Sativa with the common name of "Fennel Flower" belonging to Ranunculaceae, are growing in many 
parts of the world [16]. Four kinds of alkaloids including Nigellamine (B(2) B(1) A(2) A(1) 3) are obtained from Nigella sativa. The active ingredients of Nigella sativa aqueous extract are mainly consisting of thymol, thymoquinone, dithymoquinone, thymohydroquinone $[17,18]$. The Nigella sativa's seed is a valuable source of essential and unsaturated oils. The most important unsaturated fatty acids of this seed are linoleic acid and oleic acid [19]. Nigella sativa oils act as analgesic compounds through $x$ and $\mu 1$ Supra spinal cord receptors [20].

Mirmolai et al. (2017) tried to evaluate the effectiveness of Nigella Sativa in cyclic mastalgia so they randomly divided 72 women suffering from cyclic mastalgia into two groups: Intervention (serving $10 \mathrm{ml}$ of Foeniculum vulgare equivalent of two tablespoons daily) and Placebo (10 $\mathrm{ml}$ paraffin or two tablespoons of paraffin). The paraffin syrup and Nigella Sativa syrup containing one $\mathrm{ml}$ of paraffin oil and five $\mathrm{ml}$ of Nigella Sativa oil were mixed with water and honey. Contextually, the severity range of the pain was evaluated two months before and three months after intervention using visual analog scale (VAS) instrument (a ten cm straight line using no grading) and McGill summarized questionnaire (contained fifteen items evaluating emotional and spiritual aspects of pain). The results showed a significant difference in VAS evaluation $(\mathrm{p}$ $=0.002$ ) and no significance for McGill evaluation leading us to conclude that Nigella Sativa syrup is effective on cyclic mastalgia [21].

\subsection{Vitex agnus-castus}

The Vitex agnus-castus is a plant with fingered leaves and is commonly called as "Chaste tree". It was traditionally used in ancient Greek for treating women's fertility dysfunctions such as dysmenorrhea, infertility, menopausal complications, cyclic mastalgia, and premenstrual syndrome. This plant affects the hypothalamic-pituitary axis which leads to the release of LH, decrement of FSH and increment of progesterone, which finally cause an increment of estrogen/progesterone ratio [22]. Another theory also expresses that by the inhibition of type two dopamine receptors in pituitary gland Vitex agnus-castus which decreases prolactin production and leads to mastalgia healing.[23]

Mirmolai et al. (2016) evaluated the effect of Vitex agnus-castus on seventy-two women experiencing cyclic mastalgia. They were randomly divided into two groups: the intervention (Vitex agnus-castus syrup daily ten $\mathrm{ml}$ ) and control (paraffin syrup mixed with water and honey daily ten $\mathrm{ml}$ as placebo). The pain intensity in two months before and three months after the intervention was evaluated using VAS and McGill summarized questionnaire. The average McGill score before the intervention till the fifth month of experiment period decreased from $16.96 \pm$ 3.94 to $9.50 \pm 5.32$ and from $15.08 \pm 3.62$ to $13.08 \pm 4.29$ for Vitex agnus-castus and Placebo groups respectively(p < 0.0001 ). Also the VAS average score before the intervention till the fifth month of experiment period decreased from $6.59 \pm 3.35$ to $3.27 \pm 2.20$ and form $5.94 \pm 1.33$ to 4.94 \pm 1.81 for Vitex agnus-castus and Placebo groups respectively $(\mathrm{p}<0.0001)$. This results eventuated that Vitex agnus-castus is effective on mastalgia [24].
In another study, Sekhavat et al. (2009) also realized that the treatment with sixty drops of Vitex agnus-castus daily for three months is more effective than placebo in mastalgia treatment. At the end of the experiment period, $88.4 \%$ of patients responded to Vitex agnus-castus treatment and $17.7 \%$ of them responded to placebo treatment $(\mathrm{p}<$ 0.0001) [25]. Furthermore, Halaska and coworkers (1999) also showed that sixty drops (about three $\mathrm{mL}$ ) of Vitex agnus-castus daily for three months provides a great healing effect compared to the placebo, in the treatment of mastalgia [26].

\subsection{Comparison of Nigella sativa syrup vs. Vitex agnus-castus}

Mirmolai et al. (2015) conducted a comparative research on the effectiveness of Nigella sativa or Vitex agnus-castus in the treatment of mastalgia. In this study, 99 women suffering from cyclic mastalgia were randomly divided into 3 groups including intervention (Nigella Sativa syrup and Vitex agnus-castus syrup) and placebo (edible paraffin). The pain intensity was assessed using VAS and McGill summarized questionnaire, two months before and three months after the intervention. Changes in Vitex agnus-castus and Nigella sativa group during the study were the same with a lower slope than the placebo group. However, in the third month, the pain relief in Nigella sativa group was observed more than Vitex agnus-castus group, which shows the faster effect of Nigella sativa in comparison to Vitex agnus-castus [27].

\subsection{Oenothera biennis}

It commonly named as evening primrose, whose seeds include essential fatty acids ( $70 \%$ linoleic acid and $8-14 \%$ gamma linoleic acid) which their most important effect is healing of cyclic mastalgia [28, 29]. $\gamma$-linoleic acid is metabolized into homo $\gamma$-linoleic acid, subsequently inhibits arachidonic acid metabolites production which leads to anti-inflammatory effects [30]. Alvandipour et al. (2010) compared the effects of vitamin $\mathrm{E}$ and Oenothera biennis on one hundred women experiencing cyclic mastalgia that were randomly divided into four groups each of twenty-five and were treated by Oenothera biennis (two g per day), vitamin E (four hundred. IU daily), Vitamin E/ Oenothera biennis and placebo respectively. Pain intensity was assessed using the McGill summarized questionnaire. The analysis was conducted one month before and six months after the treatment. The McGill score in the intervention groups was significantly reduced compared to the placebo group $(p<0.0001)$. There was no significant difference between intervention groups. Based on the evidence obtained from this research, vitamin $\mathrm{E}$ and Oenothera biennis have similar therapeutic effects on cyclic mastalgia [10].

\subsection{Comparison of Oenothera biennis vs. Vi- tex agnus-castus}

It Some studies focused on the effects of Oenothera biennis/Vitex agnus-castus/Vitamin E in the treatment of cyclic mastalgia, in this case, Salehi et al. (2013) designed 
a study in 210 women experiencing cyclic mastalgia, that were randomly divided into three groups each of seventy. The first group received Vitex agnus-castus tablet (4 mg/ day), the second one was Oenothera biennis capsules (5000 mg/day) and the control group took Vitamin E (400 IU/day) for two months. Pain intensity was evaluated by Cardiff questionnaire approach (patients monthly answer it using severe, moderate and no pain in the days in which they experience mastalgia) and pain ruler (graded from zero to ten and the patients chose one of the numbers based on the intensity of the pain they experience). The average of pain score was reduced in these groups, whereas Vitex agnus-castus was more effective $(\mathrm{p}<0.0001)$ [31].

\subsection{Linum usitatissimum:}

Linum usitatissimum or flaxseed is a plant which contains unsaturated essential fatty acids (mainly omega-3) $[11,32,33]$. Linum usitatissimum possesses notable amounts of lignin phytoestrogen that inhibits aromatase action which leads to the reduction of estrogen. Lignin chemical structure is similar to estradiol and selective estrogen receptor modulators such as tamoxifen which is used in the treatment of mastalgia [34, 35].

In one study, the effects of Linum usitatissimum and omega-3 in cyclic mastalgia treatment were compared. In this study, Linum usitatissimum was processed as bread (30 g daily), which other groups received omega-3 (1 g/ day) and the routine wheat bread (control group). The pain intensity was evaluated one month before and two months after the intervention using the observational method. The results showed that Linum usitatissimum has an obvious effectiveness in ameliorating the mastalgia compared to omega-3 [1].

\subsection{Comparison of Linum usitatissimum vs. Oenothera biennis}

Jafar-Nejad et al. (2016) conducted a study to evaluate the effectiveness of Linum usitatissimum, Oenothera biennis and vitamin E on cyclic mastalgia healing. In this study, ninety women suffering from cyclic mastalgia were randomly divided into three groups: Linum usitatissimum (thirty g daily), Oenothera biennis (two thousand mg daily) and vitamin E (four hundred IU daily) and treated for two months. Pain evaluation was assessed by VAS approach. The mean score of pain intensity was reduced in all three groups. There was not any significant difference between the treated groups $(\mathrm{p}=0.764)$. All three treated groups showed similar results in pain reduction [36].

\subsection{Foeniculum vulgare}

Foeniculum vulgare belonging to Apiaceae, with the common name of fennel, is used for its root, leaves, and fruits. In addition to $10-12 \%$ of lipid contents, Foeniculum vulgare fruits possess a little bit of mucilage, essences and phenolic ethers that are the most valuable evident of medicinal application of this plant. The chief ingredients of this plant are fenchone, limonene, and trans-anethole [37].
Delaram et al. performed a study (2011) in which the participants were randomly divided into two groups each of thirty: Foeniculum vulgare group patients were treated by thirty drops of Foeniculum vulgare extract every eight hours for three days before and the first three days of the menstrual cycle that continued for two months and the placebo group served placebo for the same period of time. The clinical symptoms were assessed using the DSRP questionnaire. Pain evaluation performed using graded scores of zero to four in which zero means no pain, one Mild pain, two moderate pain and dysfunction of daily performance, three severe pain and four extremely severe pain. The result showed no significant difference in mastalgia treatment between placebo and Foeniculum vulgare groups $(\mathrm{p}=0.76)[38]$.

\subsection{Comparison of Echinosophora Platyloba vs. Foeniculum vulgare}

Echinosophora platyloba is from Apiaceae, exclusively growing in Iran and used as a food flavor. This plant is well-known by its local traditional names: Khosharooz, Khosharoozeh, Tigh toragh and Koshandar, which contain active ingredients saponin, flavonoids, and alkaloids.[39]

Delaram et al. (2011) evaluated the effects of Foeniculum vulgare, Echinosophora platyloba, or placebo on the menstruation fsymptoms (sensitivity, swelling, heaviness, breast tenderness, and pain in the breast, waist abdomen and joint). Women were randomly subjected into three groups of thirty: Echinosophora platyloba, Foeniculum vulgare, and placebo, which treated by thirty drops every eight hours for three days before menstruation and first three days of the cycle. The results showed that Foeniculum vulgare and Echinosophora Platyloba similarly reduced the premenstrual symptoms, although there was no significant difference between these groups $(\mathrm{p}=0.22)$ [40].

\subsection{Hypericum perforatum}

Hypericum perforatum is an herbal medicine plant containing various compounds and chemicals, such as anthraquinone derivatives (Naphthodianthrones), flavonoids, fluoroglosinols, tannins, hyperforin, and hypericin [41]. In the study of PakGohar et al. (2006), seventy people were randomly divided into two groups each of thirty-five patients and treated by thirty drops of Hypiran ${ }^{\circledR}$ (the Hypericum perforatum extract) or placebo two times per day at least seven days before the menstruation period for two consecutive cycles. The results revealed that physical symptoms in Hypiran and placebo group were decreased by $49 \%$ and $21.8 \%$ respectively. $75.6 \%$ reduction of the severity of mastalgia was seen in the Hypiran group [42].

\subsection{Rosa damascena}

Rosa damascena mill L., known as Gole Mohammadi, is one of the most important species of Rosaceae family flowers. Its extract is obtained from the cauliflower and petal, containing three hundred different types of com- 
pounds [43]. Rosa damascena extract is a stimulant, antidepressant, antianxiety, affecting the brain similarly to the amphetamine mechanism. Jamilian et al. (2017) investigated the effect of Omega-3 capsules and Rosa damascena extract on the symptoms of premenstrual syndrome. One hundred and twenty women were randomly divided into three groups. The first group was treated with Omega-3 capsules (500 mg daily), the second group served oral drops of Rosa damascena (30 drops/day) and the third group was treated with placebo, which administrated from fourteen days before menstruation until the end of menstruation for three consecutive cycles. The results of the study showed that Omega- 3 had a more significant effect on periodic mastalgia in comparison to Rosa damascena and placebo groups $(\mathrm{p} \leq 0.001)[44]$.

\subsection{Wheat germ}

Wheat germ contains various types of vitamins, minerals, and proteins, which is considered effective for the treatment of various diseases such as cancer, obesity, diabetes, asthma, anemia, eczema, and hypertension. By detail, it contains magnesium, zinc, calcium, selenium, sodium, potassium, phosphorus, and antioxidant compounds such as beta-carotene (vitamin A), vitamin E, vitamin C and vitamin B12, vitamin B6, thiamine, riboflavin, niacin, folic acid, iron, amino acids, and enzymes, based on the chemical analysis $[45,46]$.

Ataollahi et al. in a triple-blind clinical trial (2015) studied one hundred women that were randomly divided into two groups each of fifty. They received wheat germ extract (400 mg) or placebo three times a day from day 16th menstruation cycle to the day 5th of next cycle for two consecutive cycles. The mean reduction of physical symptoms in wheat germ extract and placebo groups was $56.63 \%$ and $14.35 \%$, respectively. After two months, mastalgia in the wheat germ group decreased about $79.71 \%$ [47].

\subsection{Citrus sinensis}

The essential oil of Citrus sinensis skin with the common name of orange includes compounds such as limonene, phellandrene, and citral having sedative, antispasmodic, antidepressant, antiemetic, and analgesic effects in central nervous system similar to fluoxetine. Ozgoli et al. (2010) conducted a double-blind clinical trial study on eighty women with the premenstrual syndrome who were randomly divided into two groups each of forty subjects serving ten drops of Citrus sinensis skin essential oil or placebo three times a day, at least fourteen days before menstruation for two consecutive cycles. Based on the results, the reduction in the severity of physical symptoms in the Citrus sinensis essential oil group was $24.30 \%$ and in the placebo group was $5 \%$ so the Citrus sinensis essential oil was more effective than placebo in the reduction of the physical symptoms of the premenstrual syndrome [48].

\subsection{Ginkgo biloba}

Tamborini et al. (1993) studied on one hundred and sixty-five people that were randomly divided into the inter- vention and control groups receiving the plant extract and placebo, respectively, daily from 16th day of menstruation cycle to the 5th day of the next cycle for two cycles. The results showed that the clinical effectiveness of this plant for treating pain and breast congestion was more than placebo [49]. The effectiveness of this plant in the treatment of pain and breast sensitivity and fluid retention has been shown by the consumption of $60-240 \mathrm{mg}$ of the standardized extract [50].

\subsection{Curcumin}

Curcumin scientifically called as Diferuloylmethane, a yellow polyphenol, and is the main ingredient of Curcuma longa and famously known as an antioxidant and anti-inflammatory compound. The antioxidant effect of curcumin is equal to vitamin $\mathrm{E}$ and $\mathrm{C}$. By prostaglandin inhibition, curcumin can be used in the treatment of inflammatory diseases, diabetes, tumors, cardiovascular, respiratory, nervous system, skin, liver, bone and menopausal symptoms [51, 52]. In Khayat's study (2015), seventy women experiencing mastalgia were randomly divided into two groups: curcumin and placebo. Patients have received two capsules per day for seven days before menstruation and also three days after the menstrual cycle for three cycles. According to the results, curcumin was more effective than placebo to reduce the symptoms in all three cycles $(\mathrm{p}=0.001)$ [53].

Sharifi et al. (2014) performed a study in which participants were randomly divided into two groups each of forty-five: intervention and control group serving five percent chamomile extract and two hundred and fifty mg of mefenamic acid respectively (at the day 21th of the menstruation cycle until the next cycle three times per day for two cycles). The results showed no significant difference between the two groups so the chamomile acts similarly to mefenamic acid in the healing of physical symptoms ( $\mathrm{p}$ $>0.05)[54]$.

\subsection{Zingiber officinale vs. Curcumin}

Zingiber officinale (ginger) from tropical plants whose dried root is used as a drug in traditional medicine [55]. Its anti-inflammatory effects may be due to the inhibition of prostaglandins and leukotrienes production [56].

In a study conducted by Khayat et al. (2014), one hundred and five women suffering from cyclic mastalgia were randomly divided into three groups: Zingiber officinale, curcumin, and placebo. Patients received two capsules of Zintoma ${ }^{\circ}(250 \mathrm{mg}$, Zingiber officinale), curcumin (100 $\mathrm{mg}$ ), and fifty $\mathrm{mg}$ capsules of starch, respectively, from 7 days before to 3 days after the menstruation cycle for 3 cycles. There was no significant difference in the severity of physical symptoms among the groups before, and one and two months after the intervention $(\mathrm{p}=0.22, \mathrm{p}=0.21$ and $\mathrm{p}=0.26$, respectively). However, in the third cycle, curcumin significantly reduced the severity of physical symptoms more than Zingiber officinale $(\mathrm{p}=0.004)$ [57].

\section{Discussion}


The present study is purposed to investigate the clinical trials conducted on medicinal herbs which can be used for treating the periodic mastalgia. Most of the published studies used Vitex agnus-castus as a treatment for mastalgia that was effective in many cases. In Mirmolaei et al. (2016) study, Vitex agnus-castus could relieve the moderate to severe pain in women with proper nutrition who were experiencing periodic pain [21]. Halaska et al. (1999) expressed that mastalgia healing in Vitex agnus-castus group was significantly more than the placebo group, also more pain reduction was observed in the third month of the study rather than the second month [26]. Sekhavat et al revealed that $88.4 \%$ of the patients responded to Vitex agnus-castus for pain reduction in comparison to $17.7 \%$ of the patients who responded to placebo.[25] In Salehi's study (2013), Vitex agnus-castus was more effective in pain relief than both Oenothera biennis and vitamin E groups [58]. In Mirmolaei's (2015) study, Nigella Sativa and Vitex agnus- castus had similar therapeutic effects for the treatment of periodic pain in the breast. Moreover, Nigella Sativa can be a good alternative to Vitex agnus-castus due to its faster therapeutic effects [27]. Vaziri et al (2014) found that Linum usitatissimum is more effective than Omega-3 [1]. However, in the study of Jafarnejad et al (2016), it had similar effects to Oenothera biennis and vitamin $\mathrm{E}$ [59]. Herbal medicines and their active constituents such as curcumin, Nigella sativa, Hypericum perforatum, Citrus sinensis essential oil, wheat germ, and Ginkgo biloba had favorable results in the treatment of mastalgia, but the probability that the articles would be published with more positive results should be considered, as well as bias in the publication. The differences between studies duration, doses, specific products and different measurements, provide it difficult to make a final comparison for these herbal compounds. Therefore, to better characterize the role of herbal medicines in mastalgia relief, further studies in addition to clinical trials including suitable duration and sufficient sample size can be more helpful. Moreover, the studies should have a suitable methodology about how to randomize, blind, and participants follow-up.

\section{Conclusion}

The results of the studies indicated a reduction in the severity of mastalgia using herbs such as Nigella sativa, Vitex agnus-castus, curcumin, Hypericum perforatum, Citrus sinensis essential oil, wheat germ, and Ginkgo biloba.

\section{Acknowledgment}

Hereby, it would be very gratefully thanks to all the researchers whose articles were used in this study.

\section{References}

1. Vaziri F, et al. Comparing the effects of dietary flaxseed and omega-3 Fatty acids supplement on cyclical mastalgia in Iranian women: a randomized clinical trial. International journal of family medicine. 2014, 2014.

2. Aydin Y, et al. Cabergoline versus bromocriptine for symptomatic treatment of premenstrual mastalgia: a randomised, open-label study. European Journal of Obstetrics \& Gynecology and Reproductive Biology, 2010;150(2):203-6.

3. Genç A, et al. The effects of exercise on mastalgia. The Physician and sportsmedicine. 2017; 45(1):17-21.

4. Pruthi S, et al. Vitamin E and evening primrose oil for management of cyclical mastalgia: a randomized pilot study. Altern Med Rev. 2010;15(1):59-67.

5. Jatoi I, K.M. Management of Breast Diseases. Mastalgia, ed. M.R. Goyal A. 2010: Springer Berlin Heidelberg.

6. Shobeiri F, K Oshvandi, M Nazari. Clinical effectiveness of vitamin $\mathrm{E}$ and vitamin $\mathrm{B} 6$ for improving pain severity in cyclic mastalgia. Iranian journal of nursing and midwifery research. 2015;20(6): 723.

7. Berek JS, N E. Berek \& Novak's gynecology. 15th ed. 2012: Philadelphia: Williams \& Wilkins.

8. Murshid K R. A review of mastalgia in patients with fibrocystic breast changes and the non-surgical treatment options. Journal of Taibah University Medical Sciences, 2011;6(1):1-18.

9. Sharami S, et al. PREVALENCE OF CYCLIC MASTALGIA AND IT'S RELATION WITH AGE, MARRIAGE AND EMPLOYMENT OUTSIDE THE HOUSE. 2000.

10. Alvandipour M, et al. Comparison between Effect of Evening Primrose Oil and Vitamin E in Treatment of Cyclic Mastalgia. Journal of Babol University Of Medical Sciences. 2011;13(2):7-11.

11. Jaafarnejad F, et al. Comparison of the Effect of Fish Oil and Vitamin E on the Severity of Cyclic Mastalgia. The Iranian Journal of Obstetrics, Gynecology and Infertility. 2013;15(39):9-15.

12. Smith RL, S Pruthi, LA Fitzpatrick. Evaluation and management of breast pain. in Mayo Clinic Proceedings. 2004. Elsevier.

13. Srivastava JK, E Shankar, S Gupta. Chamomile: A herbal medicine of the past with bright future. Molecular medicine reports. 2010;3(6):895-901.

14. Salami M, AS Nejad, H Hamidi. effect of salinity on morphological changes of Cuminum cyminum and Valeriana officinalis. Research and construction, 2007;19(3):77-83.

15. Seraji A, et al. The Effects of Evening Primrose and Vitex Agnus on Pain Scale of the Women with Cyclic Mastalgia A Clinical Trial. Complementary Medicine Journal of faculty of Nursing \& Midwifery. 2014;3(4):639-53.

16. Fong $\mathrm{HH}$, Integration of herbal medicine into modern medical practices: issues and prospects. Integrative cancer therapies. 2002;1(3):287-93.

17. Morikawa T, et al. Novel Dolabellane-Type Diterpene Alkaloids with Lipid Metabolism Promoting Activities from the Seeds of Nigella s ativa. Organic letters. 2004;6(6):869-72. 
18. Morikawa T, et al. Nigellamines A3, A4, A5, and C, new dolabellane-type diterpene alkaloids, with lipid metabolism-promoting activities from the Egyptian medicinal food black cumin. Chemical and pharmaceutical bulletin. 2004;52(4):494-7.

19. Nickavar B, et al. Chemical composition of the fixed and volatile oils of Nigella sativa L. from Iran. Zeitschrift für Naturforschung C. 2003;58(9-10):629-31.

20. Al-Ghamdi M. The anti-inflammatory, analgesic and antipyretic activity of Nigella sativa. Journal of ethnopharmacology, 2001;76(1):45-8.

21. Mirmolaei ST, et al. The effect of Nigella Sativa syrup on the relief of cyclic mastalgia: A triple-blind randomized clinical trial. Journal of hayat. 2017;23(1):33-43.

22. Shahhosseini Z, A.G, Salehi Sormaghi MH, Danesh M, Abedian K, Clinical evaluation of anti- dysmenorrhea vitagnus. journal of Mazandaran University of medical science. 2006;15(50):15-21.

23. Salehi A, Momeni H, Seraji A. Comparison of the effects of Hypericum and Vitex agnus premenstrual syndrome compared with vitamin E: a randomized clinical trial. Complementary Medicine Journal of faculty of Nursing \& Midwifery. 2013;3(1):395-405.

24. Mirmolaei S, et al. The Effect of Vitagnus on Cyclic Breast Pain in Women of Reproductive Age. Journal of Babol University of Medical Sciences. 2016;18(9):7-13.

25. Sekhavat L, T Zare Tarzejani, P Kholase zadeh. The effect of vitex agnus-castus on mastalgia in women. Iranian South Medical Journal. 2009;11(2):147-152.

26. Halaska M, et al. Treatment of cyclical mastalgia with a solution containing a Vitex agnus castus extract: results of a placebo-controlled double-blind study. The Breast. 1999;8(4):175-181.

27. Moridani AS. Effect of Nigella sativa and Vitex agnus on severity mastalgia durig the female reproductive. School of Nursing and Midwifery. Journal of Tehran University of Medical Sciences. 2015.

28. Ghasemnezhad A, Honermeier B. Yield, oil constituents, and protein content of evening primrose (Oenothera biennis L.) seeds depending on harvest time, harvest method and nitrogen application. Industrial crops and products. 2008;28(1):17-23.

29. Cornish S, Mehl-Madrona L. The role of vitamins and minerals in psychiatry. Integrative medicine insights, 2008;3:33.

30. Fathizadeh N, et al. Effects of evening primrose oil and vitamin $\mathrm{E}$ on the severity of periodical breast pain. Iranian Journal of Nursing and Midwifery Research. 2009;13(3).

31. Momeni H, Salehi A, Seraji A. The Effects of Vitex Agnus Castus and Vitamin E on Anxiety in women with Mastalgia: A Randomized Clinical Trial. Knowledge \& Health. 2013;2(9).

32. Meschino JP. Flaxseed supplementation: an integral aspect of vibrant health. Dynamic Chiropract. 2003;21(2):34.

33. R, B., Novel herbal therapy. first ed. 2005, kashan: motarjem.

34. Ingram D, et al. A double-blind randomized controlled trial of isoflavones in the treatment of cyclical mastalgia. The Breast. 2002;11(2):170-4.
35. Thompson L.U, et al. Dietary flaxseed alters tumor biological markers in postmenopausal breast cancer. Clinical cancer research. 2005;11(10):3828-35.

36. Jaafarnejad F, et al. Compare the effect of flaxseed, evening primrose oil and Vitamin $\mathrm{E}$ on duration of periodic breast pain. Journal of Education and Health Promotion. 2017;6:85.

37. Vaezi G, Amoozade KM, Keramati K, Interaction Of Antinociceptive Intraperitoneal Injection Of Extract Of Foeniculum Vulgare Fruit And Morphine In Mice. Journal Of Animal Biology. 2010;2:57-63.

38. DELARAM M, JAFARI F. The effect of fennel on the pre-menstrual syndrome. KNOWLEDGE AND HEALTH. 2011;6:1-6.

39. Sadraei H, Asghari G, YAGHOBEI K. Study of the effect of hydro-alcholic and essential oil of Echinophora platyloba on rat isolated ileum contractions in vitro. JOURNAL OF RESEARCH IN MEDICAL SCIENCES (JRMS). 2003;7:150-5.

40. Delaram M, S Kheiri, Hodjati M.R. Comparing the effects of Echinophora-platyloba, Fennel and Placebo on pre-menstrual syndrome. Journal of reproduction \& infertility. 2011;12(3):221.

41. Barnes J, Anderson LA, Phillipson JD. St John's wort (Hypericum perforatum L.): a review of its chemistry, pharmacology and clinical properties. Journal of pharmacy and pharmacology. 2001; 53(5):583-600.

42. Pakgohar M, et al. Effect of Hypericum perforatum L. for treatment of premenstrual syndrome. Journal of Medicinal Plants, 2005;3(15):33-42.

43. Zarghami M, Farzin D, Bagheri K. Anti depressant effects of Rosa Damascena on laboratory rats (A controlled experimental blind study). Journal of Mazandaran University of Medical Sciences. 2001;11(33):27-33.

44. Jamilian M, Jamilian H, Mirzaie S. Rose Damascena vs. Omega-3 in the Treatment of Premenstural Syndrome:A randomized, and Placebo-Controlled Clinical Trial. complementary Medicine Journal. 2013;3(3):541-51.

45. Singh N, Verma P, Pandey B. Therapeutic potential of organic Triticum aestivum Linn.(Wheat Grass) in prevention and treatment of chronic diseases: An overview. International Journal of Pharmaceutical Sciences and Drug Research. 2012;4(1):10-4.

46. Shah K, Kapupara P, Desai T, Determination of sodium, potassium, calcium and lithium in a wheat grass by flame photometry. Pharma Science Monitor An International Journal of Pharmaceutical Sciences. 2011:900-9.

47. Ataollahi M, et al. The effect of wheat germ extract on premenstrual syndrome symptoms. Iranian journal of pharmaceutical research. IJPR. 2015;14(1):159.

48. Ozgoli G, et al. Essential oil of Citrus sinensis for the treatment of premenstrual syndrome; a randomized double-blind placebo-controlled trial. Journal of Reproduction \& Infertility. 2011; 12(2).

49. Tamborini A, Taurelle R. Value of standardized Ginkgo biloba extract (EGb 761) in the management of congestive symptoms of premenstrual syndrome. Revue francaise de gynecologie et d'obstetrique. 1993;88(79):447-57.

50. JS, B., Novak's gynecology. 14 ed. 2012, tehran: golban 
publication.

51. Sugawara J, et al. Effect of endurance exercise training and curcumin intake on central arterial hemodynamics in postmenopausal women: pilot study. American journal of hypertension. 2012;25(6):651-6.

52. Sabetkasaei M, et al. The study of the neuroprotective effects of curcumin, against homocysteine intracerebroventricular injection -induced cognition impairment and oxidative stress in the rat. Physiology and Pharmacology. 2009;13(3):328-39.

53. Khayat $\mathrm{S}$, et al. The effect of curcumin on premenstrual syndrome symptoms: a double-blind randomized clinical trial. Journal of Nursing and Midwifery Urmia University of Medical Sciences. 2016;13(11):935-44.

54. Sharifi F, et al. Comparison of the effects of Matricaria chamomila (Chamomile) extract and mefenamic acid on the intensity of premenstrual syndrome. Complementary therapies in clinical practice. 2014;20(1):81-8.

55. Heitmann K, Nordeng H, Holst L. Safety of ginger use in pregnancy: results from a large population-based cohort study. European journal of clinical pharmacology. 2013;69(2):269-77.

56. Baliga MS, et al. Update on the chemopreventive effects of ginger and its phytochemicals. Critical reviews in food science and nutrition, 2011;51(6):499-523.

57. Khayat S, et al. Comparison the effects of Ginger and Curcumin in treatment of premenstrual syndrome. Iranian South Medical Journal (ISMJ). 2015;18:575-86.

58. =Salehi A, Momeni H, Seraji A. The effect of Evening Primrose and Vitex on cyclic Mastalgia in comparison with vitamin E: a randomized clinical trial. Scientific Magazine Yafte. 2013;15(2):95-109.

59. JAFARNEJAD F, et al. Comparison of the effect of fish oil and vitamin $\mathrm{E}$ on duration of cyclic mastalgia. Evidence Based Care. 2013;3:69-76. 